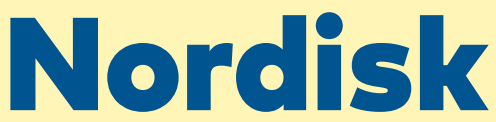

statistik

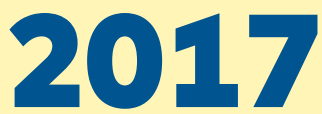

(1) Nordiska ministerrådet 


\section{Nordisk statistik 2017}

Red: Klaus Munch Haagensen, Danmarks Statistik, Ulla Agerskov, Nordiska ministerådet

Databas: Troels A. Vestergaard, Danmarks Statistik

ANP 2017:747

ISBN 978-92-893-5097-6 (PRINT)

ISBN 978-92-893-5098-3 (PDF)

ISBN 978-92-893-5099-0 (EPUB)

ISSN 2414-6560 (ONLINE)

ISSN 2414-6552 (PRINT)

http://dx.doi.org/10.6027/ANP2017-747

(c) Nordiska ministerrådet 2017

Layout: Mette Agger Tang

Tryck: Specialtrykkeriet Arco

Printed in Denmark

\section{Det nordiska samarbetet}

Det nordiska samarbetet är ett av världens mest omfattande regionala samarbeten. Det omfattar Danmark, Finland, Island, Norge och Sverige samt Färöarna, Grönland och Åland.

Det nordiska samarbetet är politiskt, ekonomiskt och kulturellt förankrat och en viktig del av europeiskt och internationellt samarbete. Den nordiska gemenskapen arbetar för ett starkt Norden i ett starkt Europa.

Det nordiska samarbetet vill styrka nordiska och regionala intressen och värderingar i en global omvärld. Gemensamma värderingar länderna emellan bidrar till att stärka Nordens ställning som en av världens mest innovativa och konkurrenskraftiga regioner. 
Nordisk statistik 2017 
Mer statistik på

www.norden.org/fakta 


\section{Förord}

De nordiska länderna är små var för sig, men tillsammans är de betydelsefulla. Visste du till exempel att om man slår samman ländernas bruttonationalprodukter blir Norden världens tolfte största ekonomi? Eller att regionen Norden är större än hela Indien och därmed den sjunde största i världen?

Den här fickversionen av Nordisk statistik 2017 ger dig en liten inblick i statistiken som tecknar konturerna av våra nordiska samhällen - till exempel att invånarna på Island i snitt går på teater dubbelt så ofta som man gör i Norge, Danmark och Sverige.

Om du vill fördjupa dig ytterligare i nordisk statistik kan du besöka www.norden.org/fakta. Där hittar du databasen Nordisk statistikbank och fler siffror som öppnar för många intressanta analyser.

Trevlig läsning! 


\section{Symboler}

Noll

Mindre än hälften

0

Inte tillämpligt

Uppgift saknas

Länk till databas

\section{Landskoder}

Danmark DK

Färöarna FO

Grönland GL

Finland $\mathrm{FI}$

Åland

AX

Island

IS

Norge

NO

Sverige

SE

Norden

NR

Euroområdet

EA

Europeiska unionen

EU 


\section{Innehåll / teman}

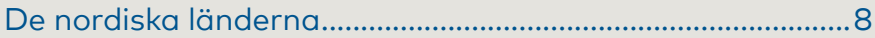

Norden i ett internationellt sammanhang........................... 10

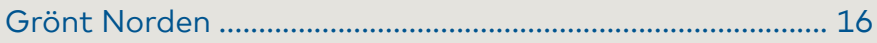

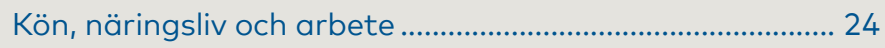

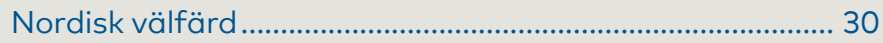

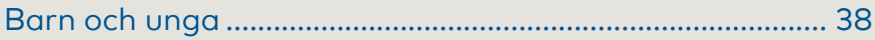

Innovation och kreativitet ...................................................... 48

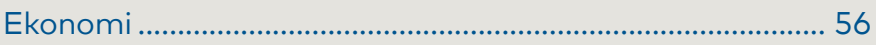




\section{De nordiska länderna}

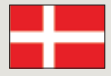

Danmark

Areal km²

42926

Befolkning

5748769

Statsskick/status

Konstitutionell monarki

Statsöverhuvud

Drottning Margrethe II

Huvudstad

1295686 (Köpenhamn)

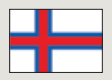

\section{Färöarna}

Areal km²

Befolkning

1396

Statsskick/status 49864

Statsöverhuvud

Huvudstad

Självstyre, del av kungariket Danmark Drottning Margrethe II 20885 (Torshamn)

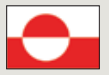

\section{Grönland}

Areal km²

Befolkning

2166086

Statsskick/status

Statsöverhuvud

Huvudstad

\section{0}

Självstyre, del av kungariket Danmark Drottning Margrethe II

17600 (Nuuk)

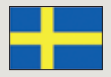

\section{Sverige}

Areal km²

447435

Befolkning

9995153

Statsskick/status

Konstitutionell monarki

Statsöverhuvud

Kung Carl XVI Gustav

Huvudstad

2269060 (Stockholm) 


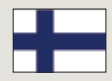

Finland

Areal km² $\quad 338430$

Befolkning $\quad 5503297$

Statsskick/status Republik

Statsöverhuvud President Sauli Niinistö

Huvudstad 1138502 (Helsingfors)

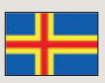

\section{Åland}

Areal km²

1581

Befolkning

29214

Statsskick/status

Självstyre, del av republiken Finland

Statsöverhuvud

Huvudstad

President Sauli Niinistö

11565 (Mariehamn)

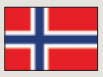

\section{Norge}

Areal km²

Befolkning

Statsskick/status

Statsöverhuvud

Huvudstad

\section{1}

5258317

Konstitutionell monarki

Kung Harald V

1281127 (Oslo)

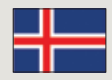

\section{Island}

Areal km²

103492

Befolkning

338349

Statsskick/status

Republik

Statsöverhuvud

Huvudstad

President Guðni Jóhannesson

216878 (Reykjavik) 


\section{NYCKELTAL 2016*}

\section{Norden i ett}

internationellt

sammanhang

*2016 eller senast tillgängliga siffror. Norden består i denna tabell av Danmark, Finland, Island, Norge och Sverige. PPS: Purchasing power standards - köpkraftspariteter som eliminerar skillnader i prisnivå mellan länderna. 


\section{Landareal}

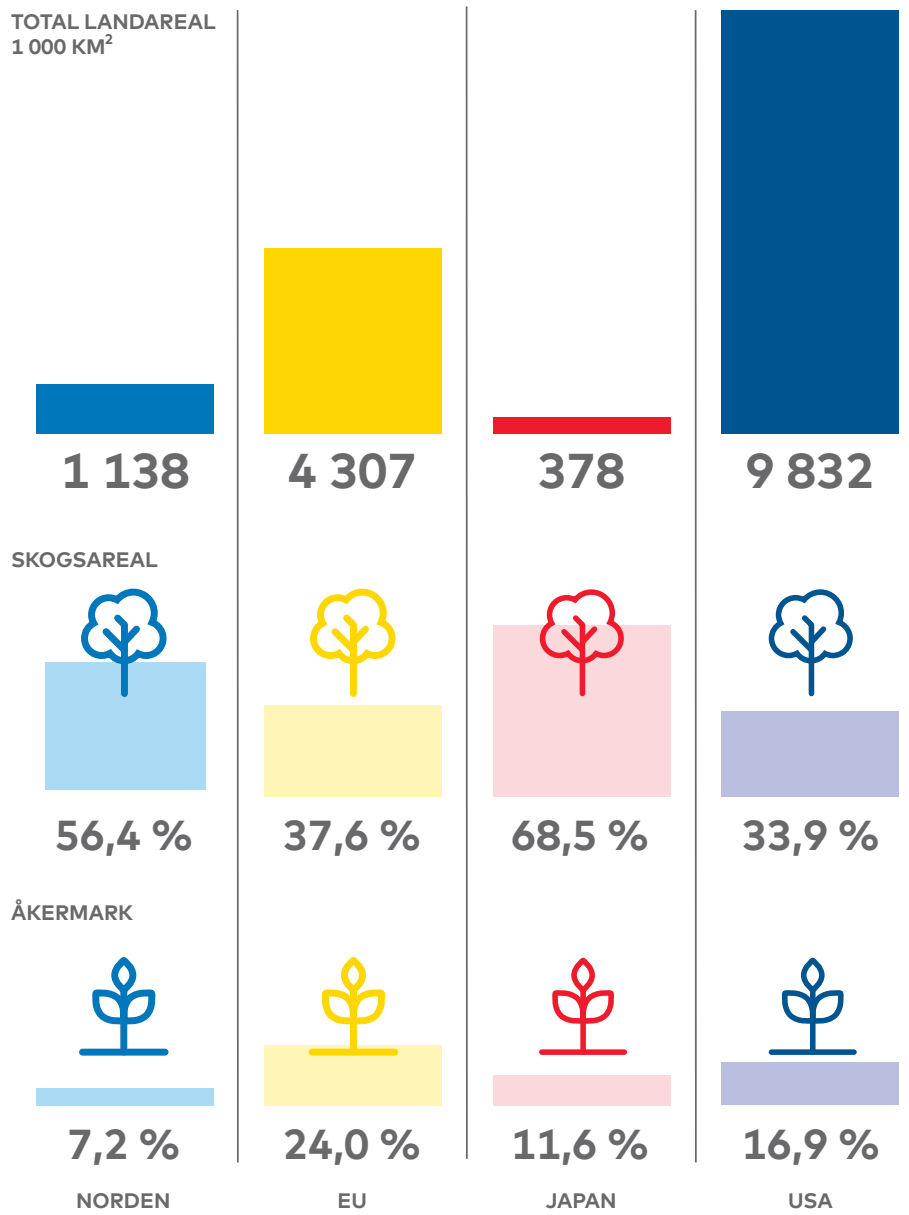




\section{Folkmängd}

miljoner
NORDEN
27 iाi
EU
JAPAN

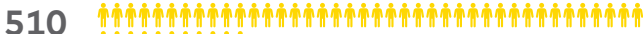
USA
127 m

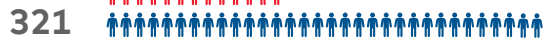

\section{Befolkningstäthet}

invånare $/ \mathrm{km}^{2}$

NORDEN

EU

17

118

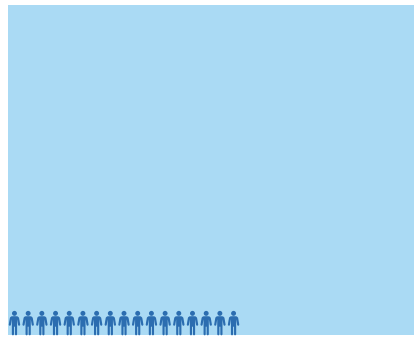

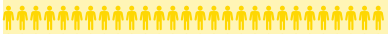

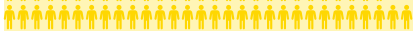

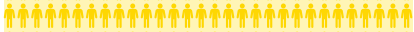

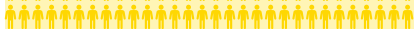

JAPAN

USA

348

35

คัน

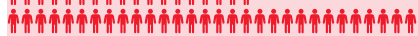
กำ

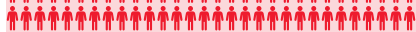

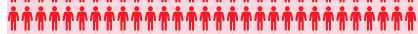

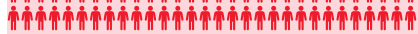

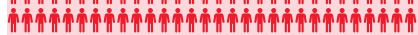

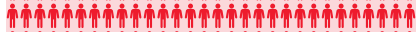

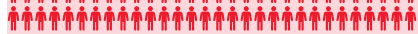

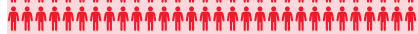

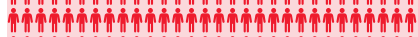

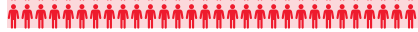


Summerade fruktsamhetstal
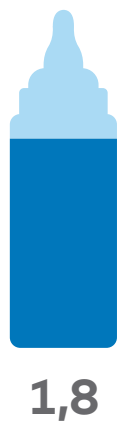

NORDEN
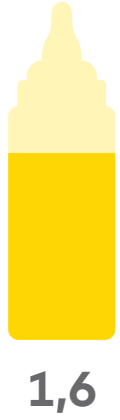

EU

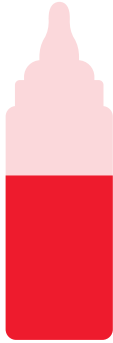

1,5

JAPAN

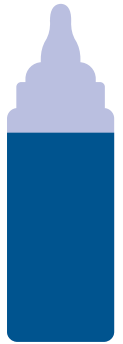

1,8

USA

\section{Medellivslängd}

år
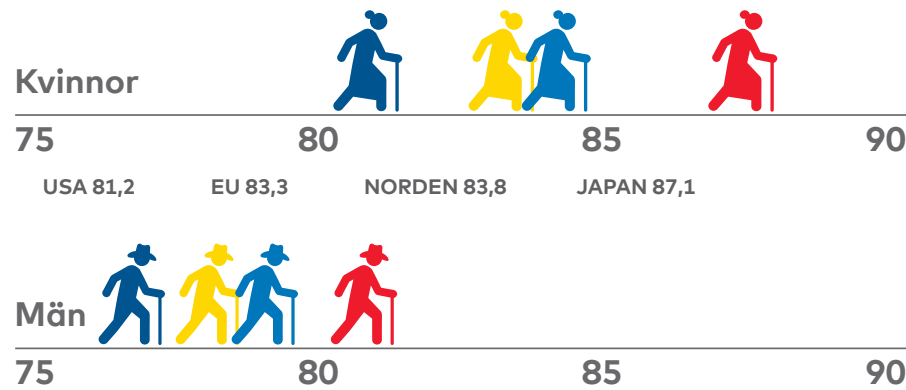

USA 76,4

EU 77,9

NORDEN 79,8

JAPAN 80,8 


\section{BNP}
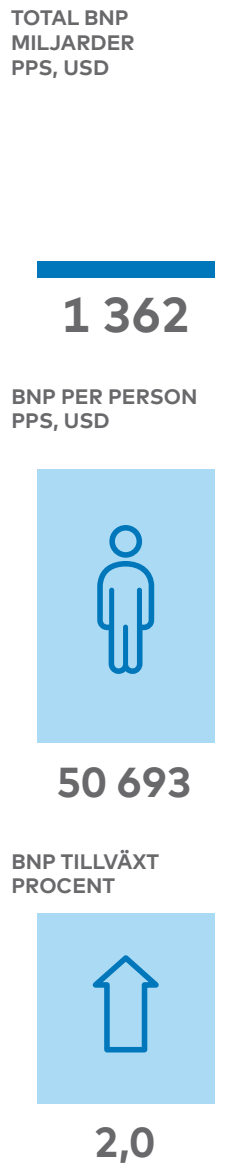

NORDEN

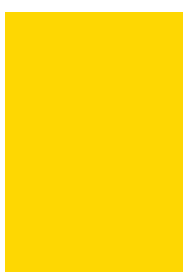

19904

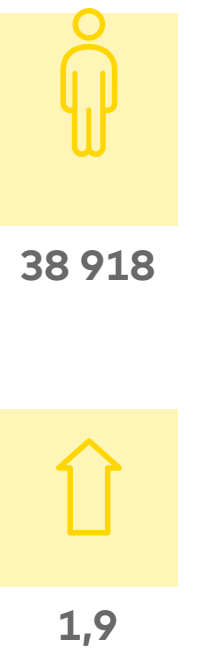

EU

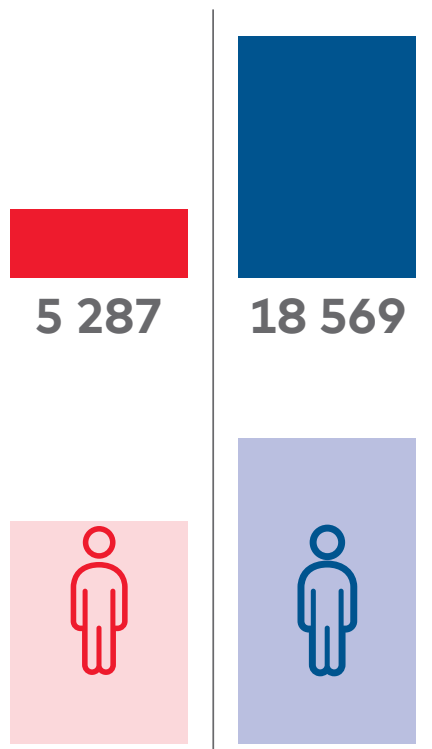

56066
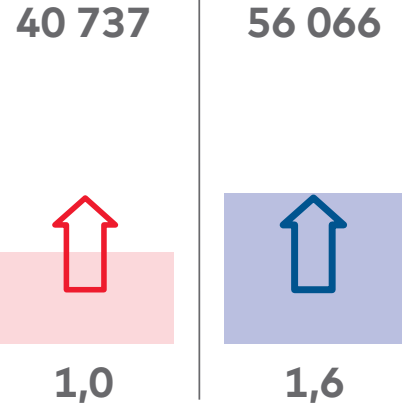

USA 


\section{Skatter}

procent av BNP

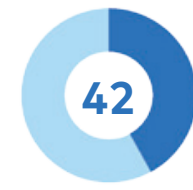

NORDEN

\section{7}

EU

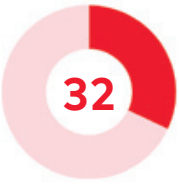

JAPAN

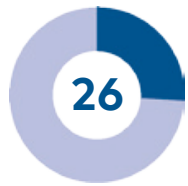

USA

\section{Export / import}

miljarder USD

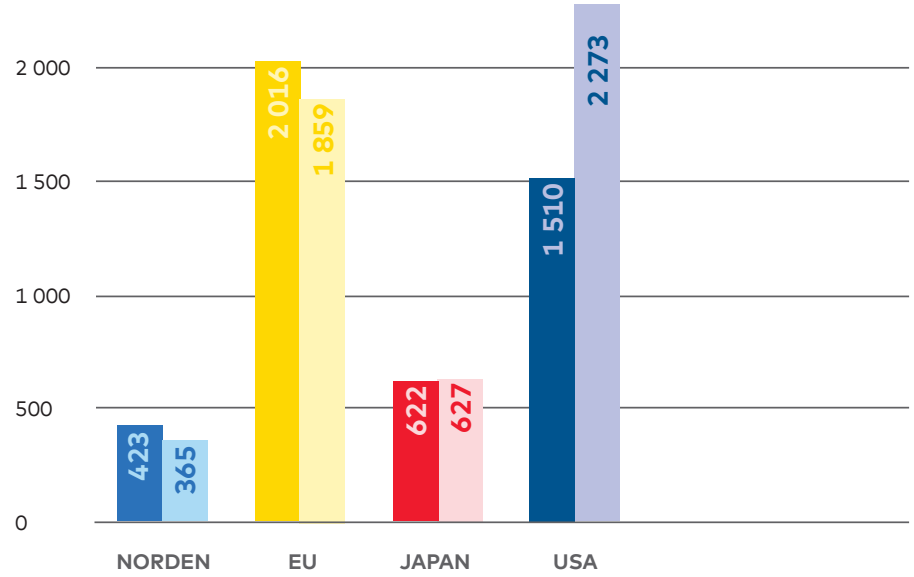




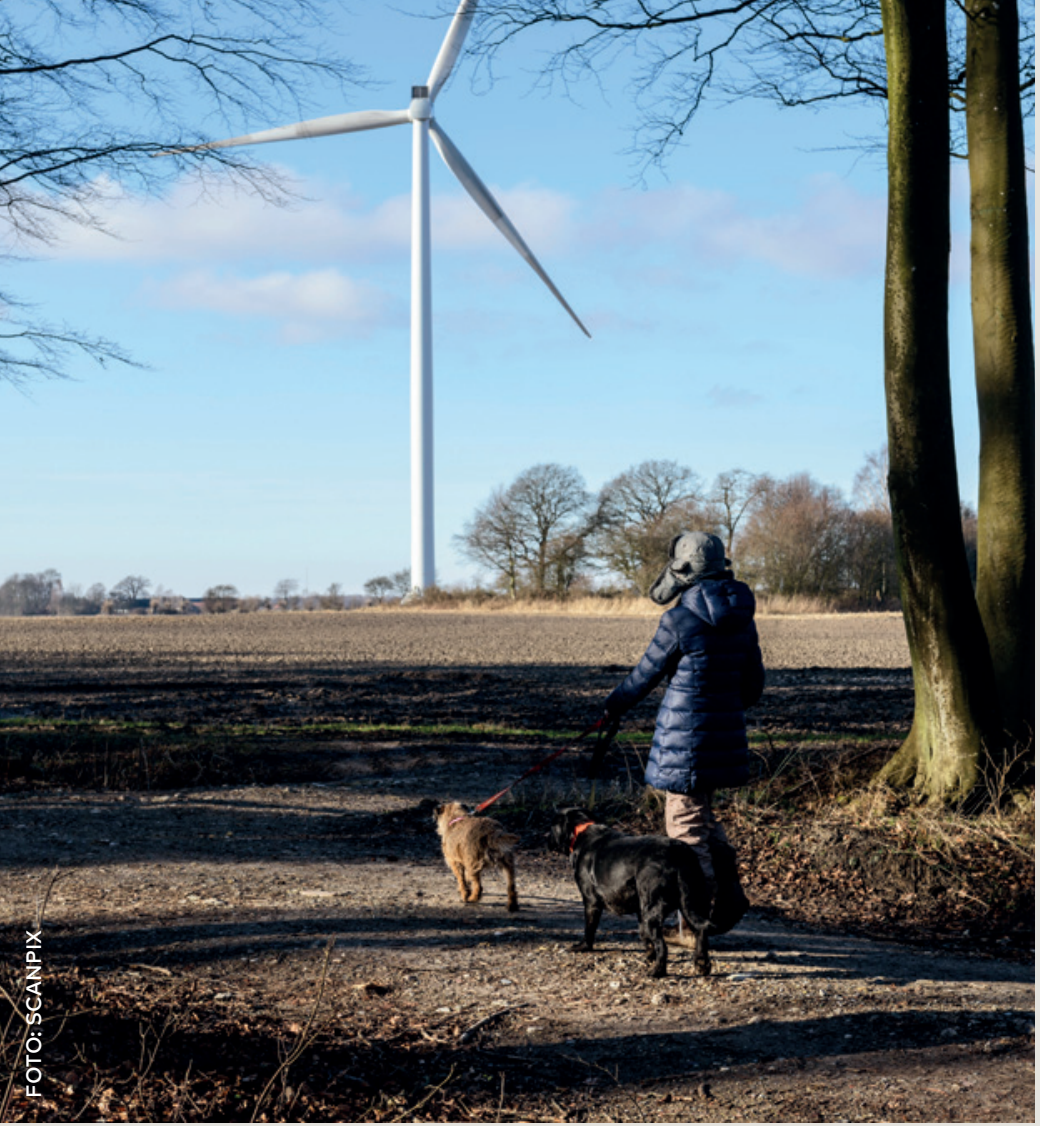

Sedan 2000 har de nordiska ekonomierna ökat med 28 procent, samtidigt har koldioxidutsläppen minskat med 18 procent. 
Grönt Norden 
Medeltemperatur i de nordiska huvudstäderna

10 Grader Celsius

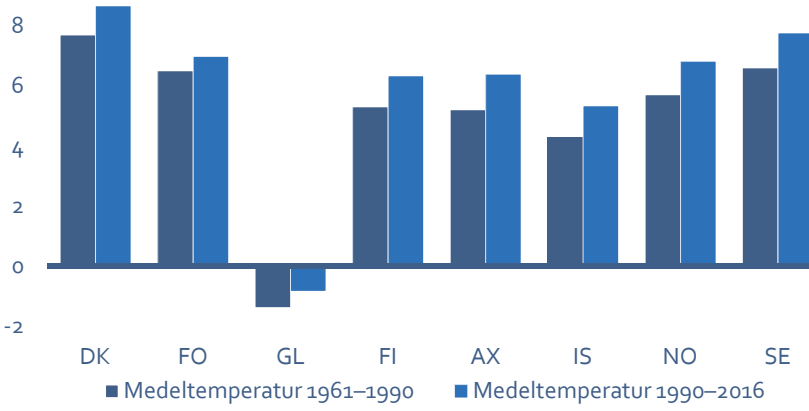

E Tempo1. Island: 1997-2016 års uppgifter.

Utsläpp av växthusgaser, per person

$16 \mathrm{CO}_{2}$-ekvivalenter, ton

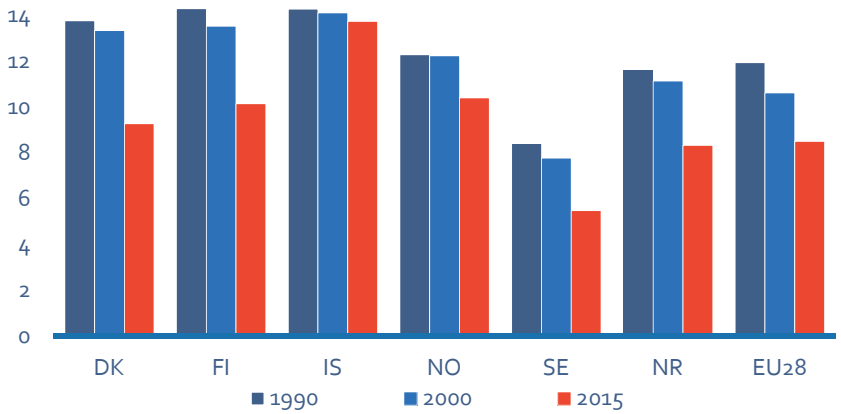

ㅌmis11 och Popuo2 


\section{Avlänkning mellan miljöbelastning och ekonomisk tillväxt}

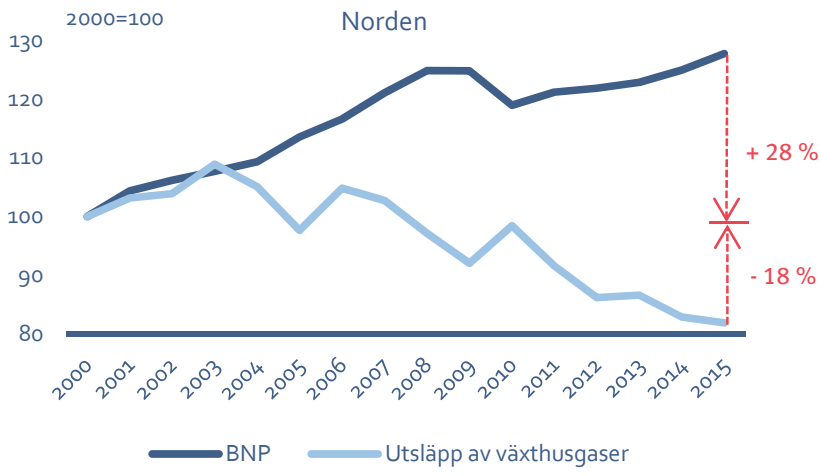

․ Emis11 och Naaco1

Avlänkning mellan miljöbelastning och ekonomisk tillväxt

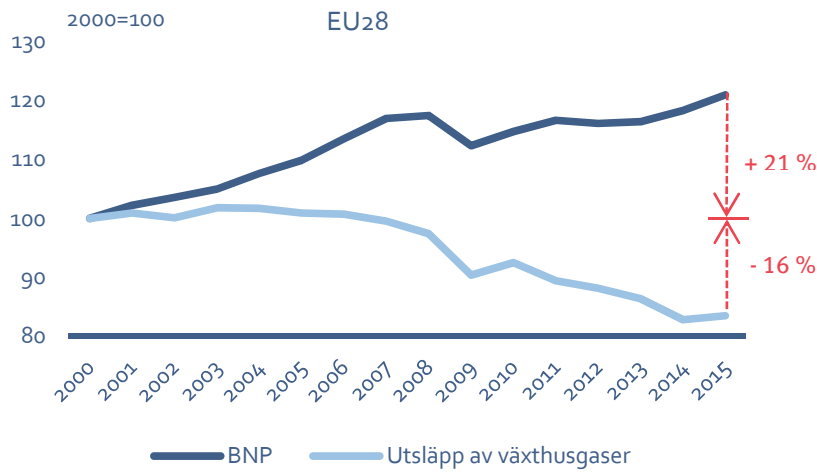

旦 Emis11 och Naaco1 
Förnybar energi 2015

procent av slutlig energiförbrukning (brutto)

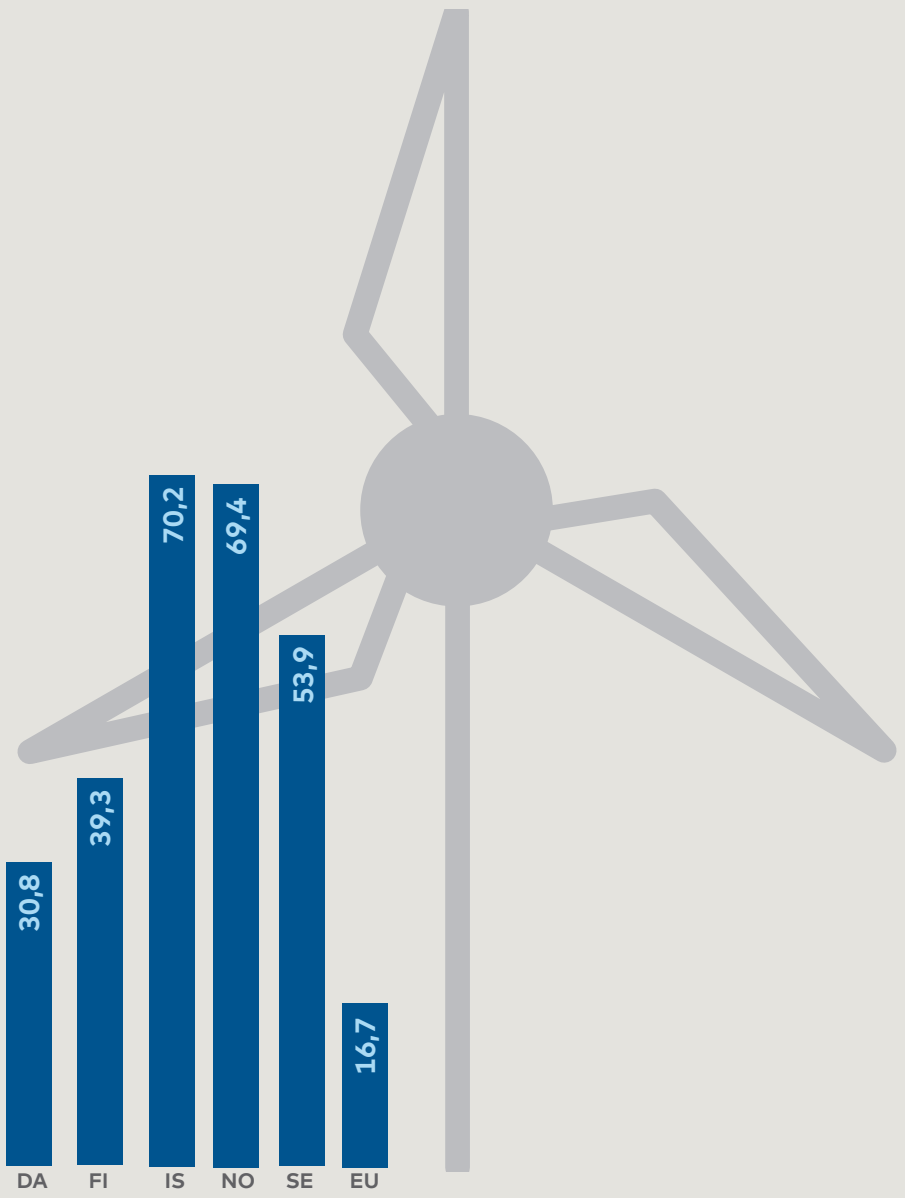




\section{Förnybar energi 2015}

\section{procent av total energiförbrukning (brutto)}

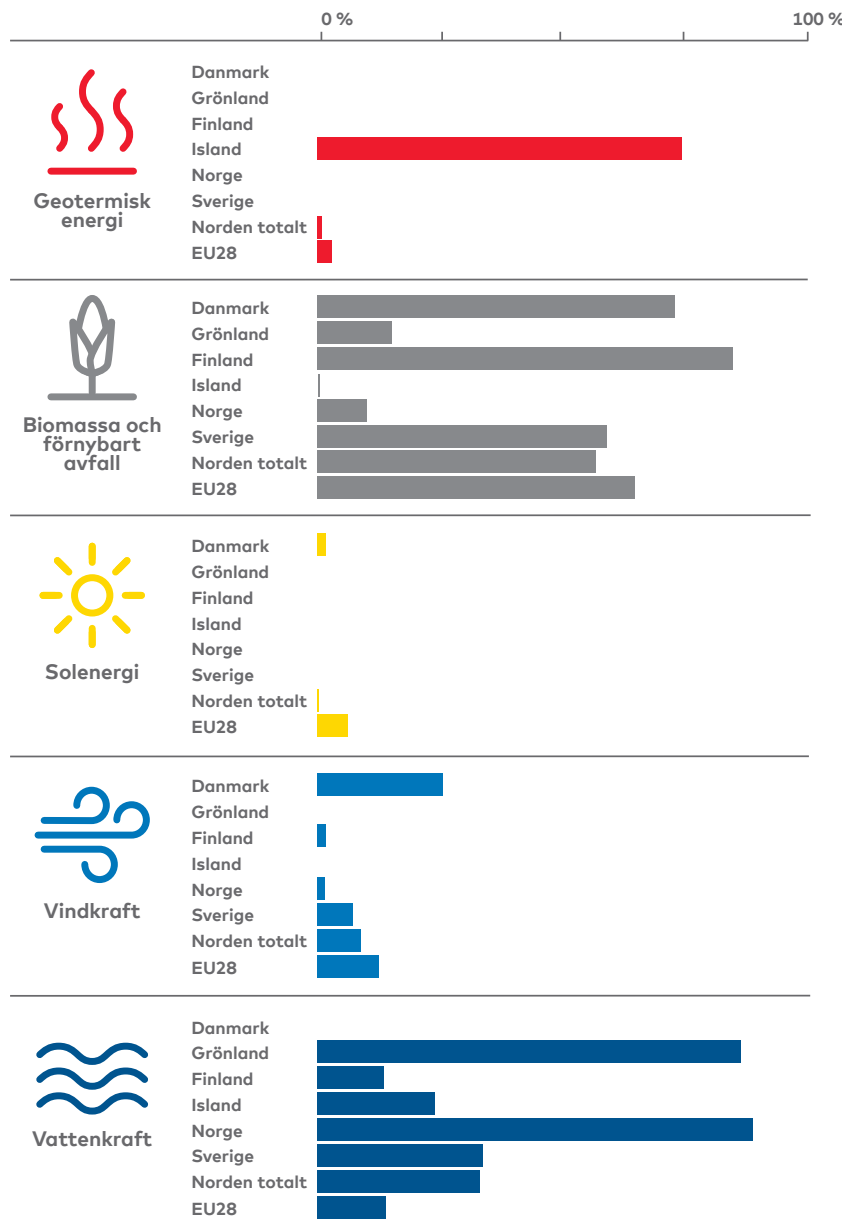


Den totala inhemska energiförbrukningen 2015

Norden

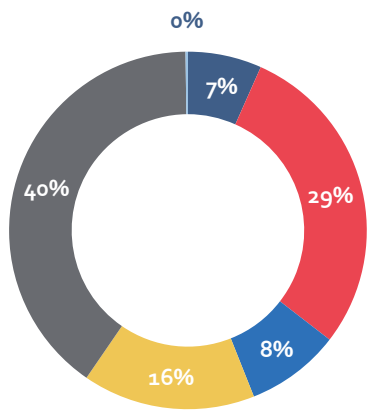

- Kol

- Olja

- Gas

- Kärnkraft

— Förnyelsebara bränslen

- Övrigt

Enero5

Den totala inhemska energiförbrukningen 2015

$\mathrm{EU}_{28}$

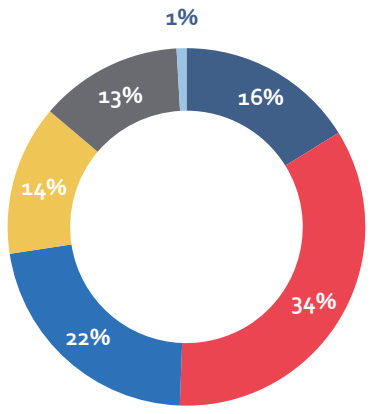

- Kol

- Olja

- Gas

- Kärnkraft

- Förnyelsebara bränslen

- Övrigt

트ero5 


\section{Miljöskatter}

8 Procent av totala skatter

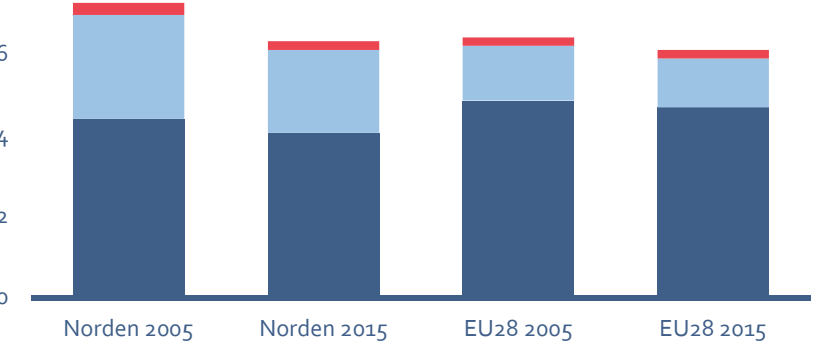

— Skatter på föroreningar och naturtillgångar —Transportskatter —Energiskatter

Envtxo1 


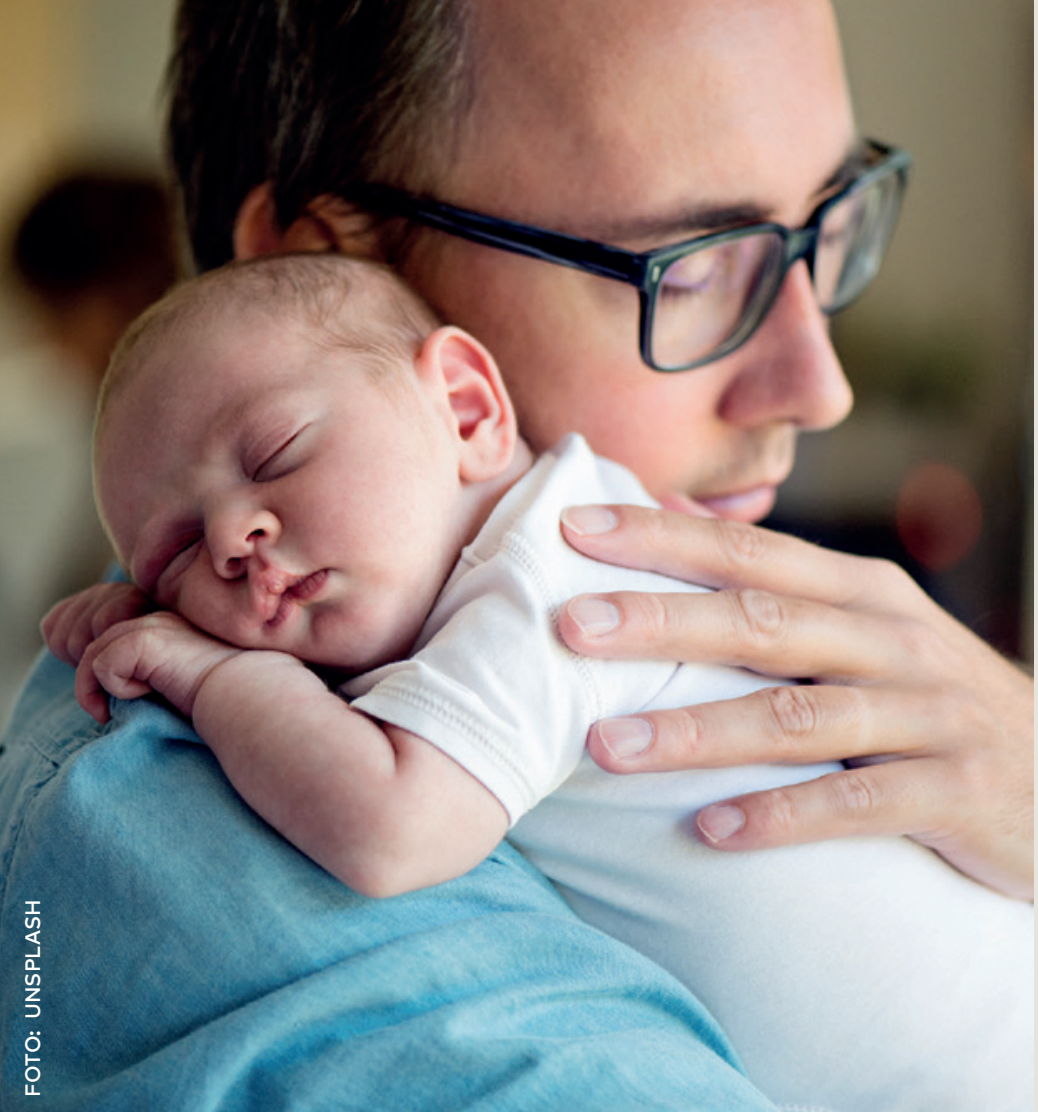

I Norden är 7 av 10 kvinnor sysselsatta.

I EU är 5 av 10 kvinnor det. 


\section{Kön, näringsliv och arbete}


Sysselsättningsgrad 2016

100 Procent av åldersgruppen 15-64 år

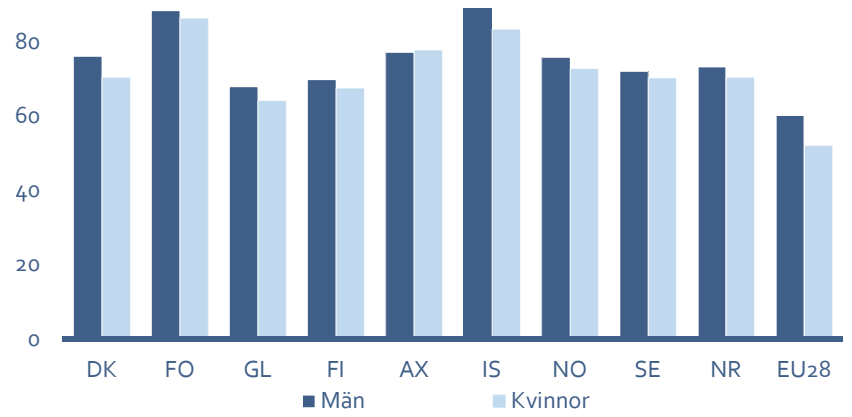

@ Work02. Grönland:2014. Åland: 2015 års uppgifter.

\section{Arbetslöshet 2016}

10 Procent av åldersgruppen 15-64 år

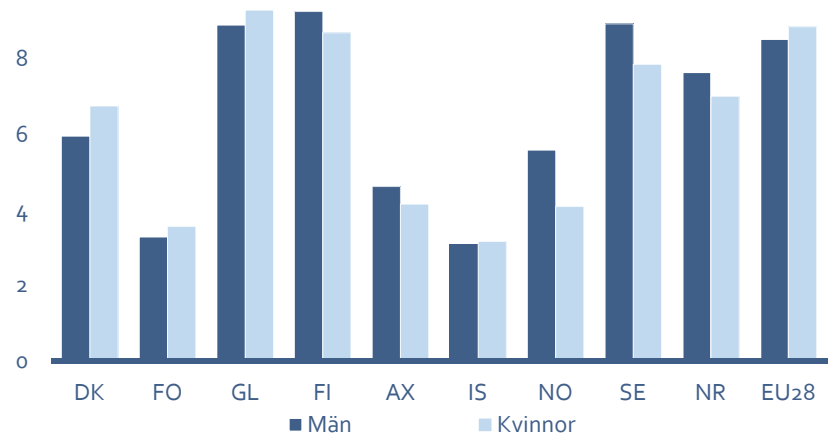

口 Work02. Grönland och Åland: 2015 års uppgifter. 
Alla sysselsatta efter kön 2016

Norden

$\mathrm{EU}_{28}$
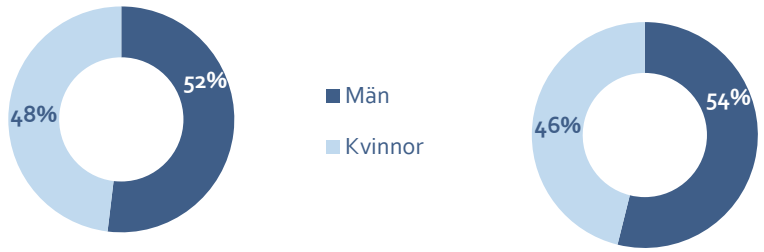

\section{Löneklyftan mellan könen}

procent
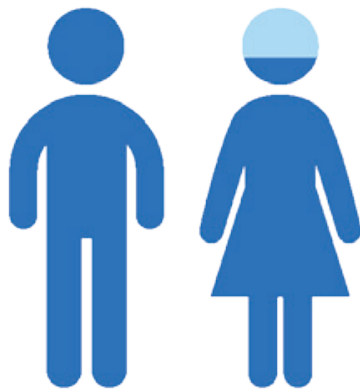

15,3

• Män

Kvinnor

NORDEN

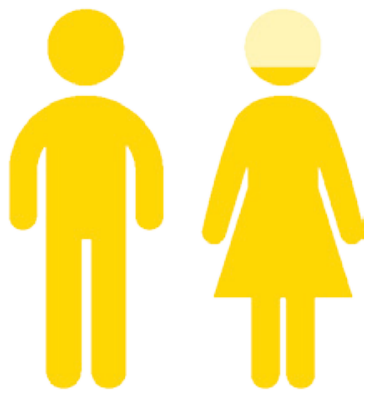

16,3

EU28 
Styrelseledamöter i större börsnoterade bolag 2015

\section{Procent}

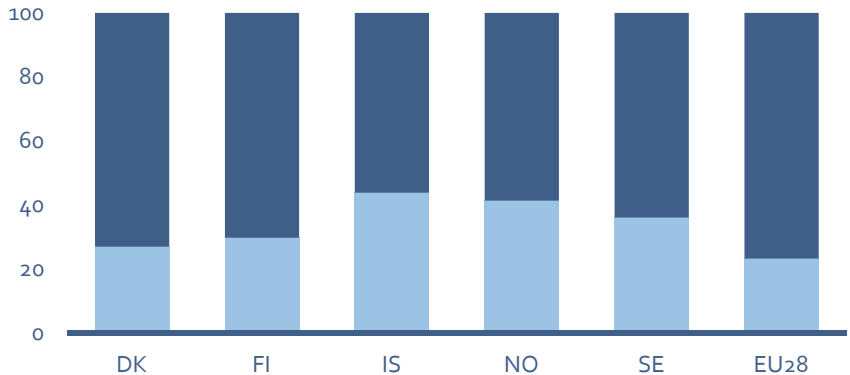

Kvinnor

- Män

口 Laboo8

Andel sysselsatta som är arbetsgivare 2015

7 Procent

6

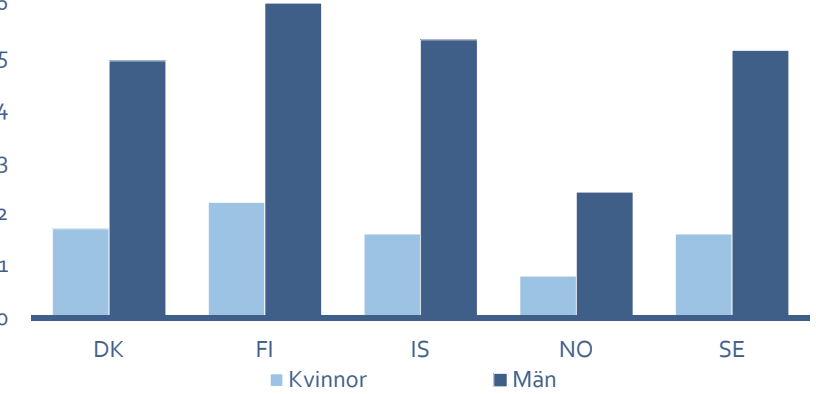

․aboog 
Mäns andel av föräldraledigheten procent

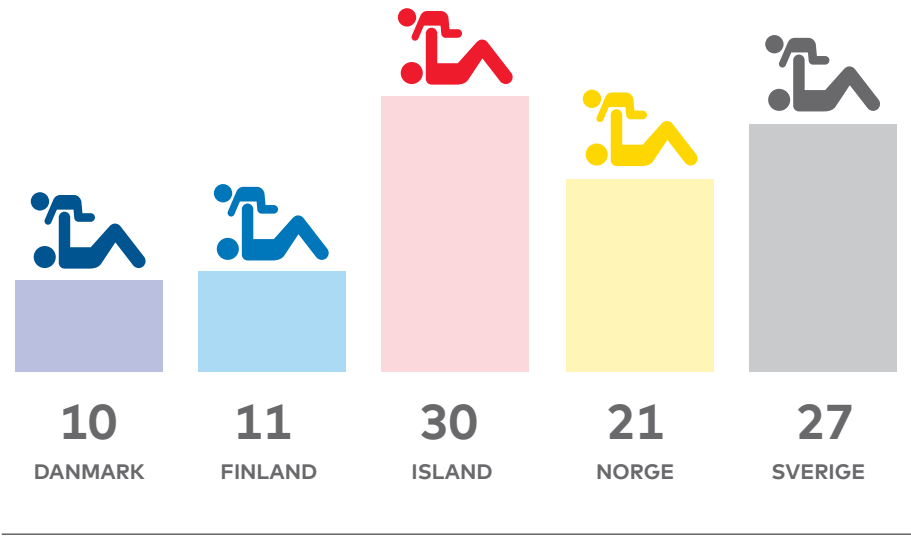

Graviditets- och föräldraledighet

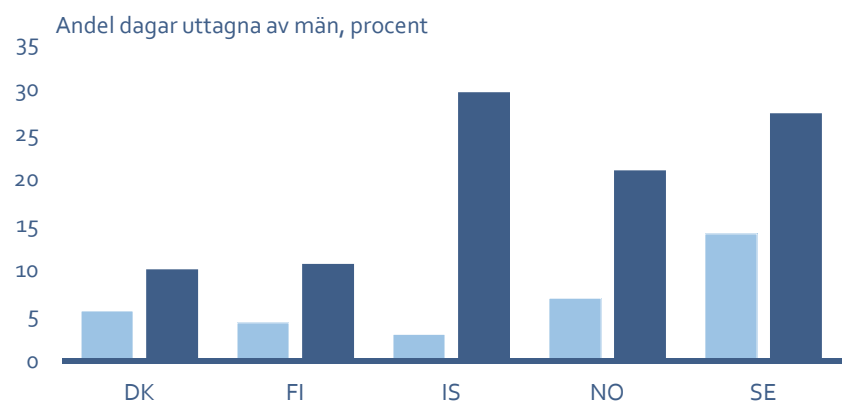

$2000 \square 2015$

Docio 4 
Nordisk välfärd 


\section{Ginikoefficient}

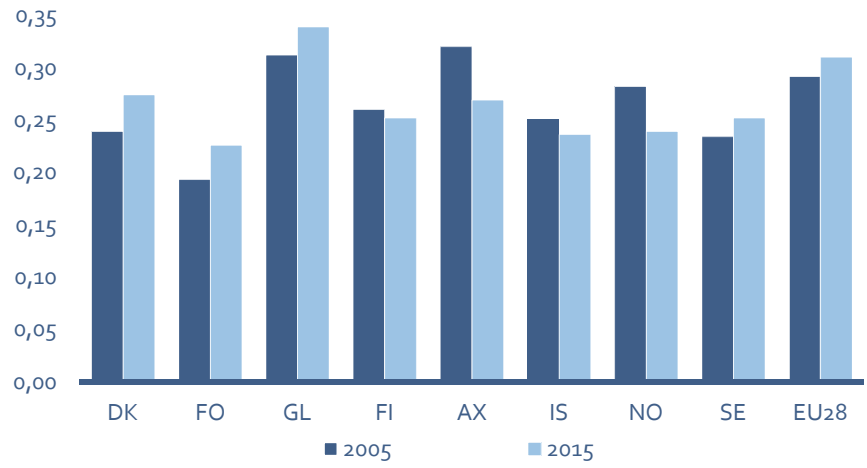

马 Ginio1. Färöarna: 2009 och 2014 års uppgifter. Åland: 2014 års uppgifter.

\section{Risk för fattigdom 2016}

40 Procent av hushållen

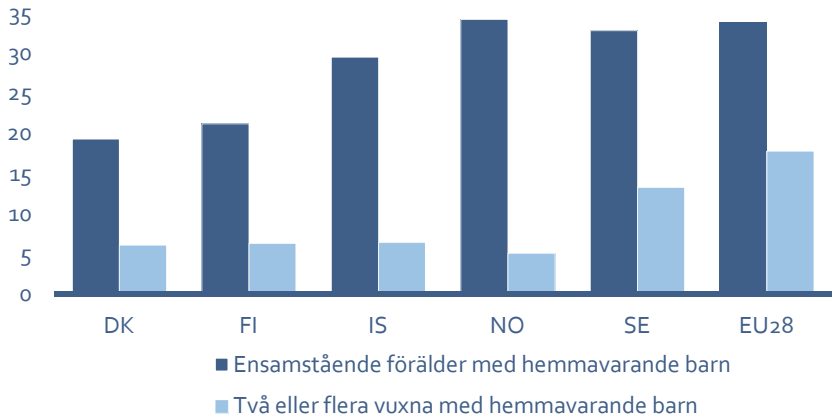

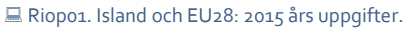




\section{Mottagare av försörjningsstöd}

4

Procent av befolkningen i åldern 18+

3

2

1

0

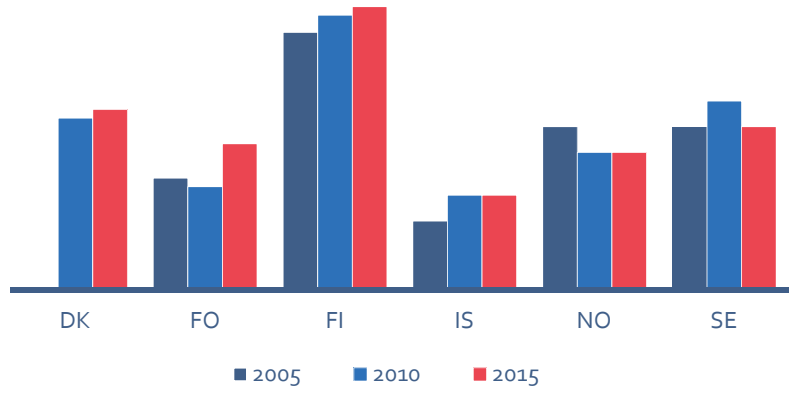

巴 Soci12. Finland: $2015=2014$ års uppgifter.

Sociala utgifter efter finansieringskälla 2014

Procent av de totala utgifterna

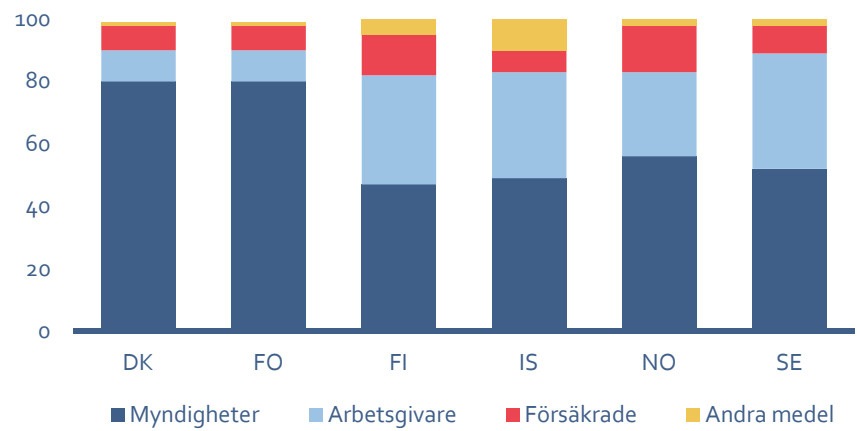

马 Soexo6 
Äldre befolkning (65+)

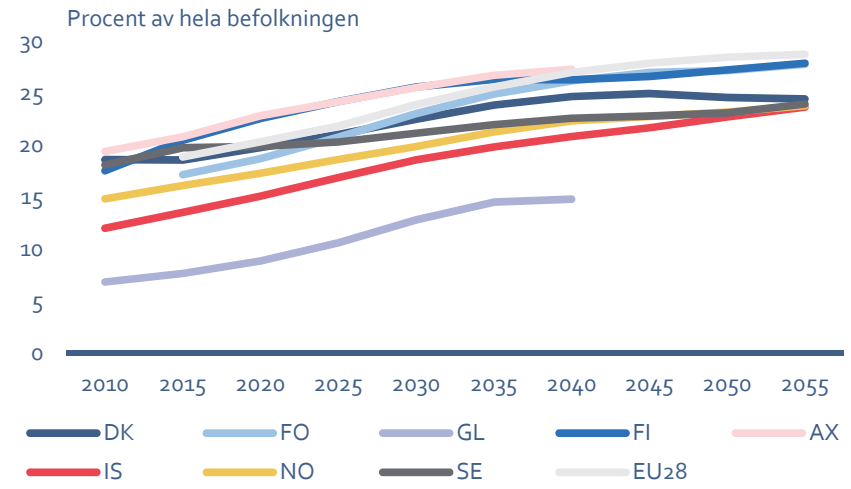

马 Popuo6

Antal dödsfall i cancer 2014

350 Per 100000 invånare

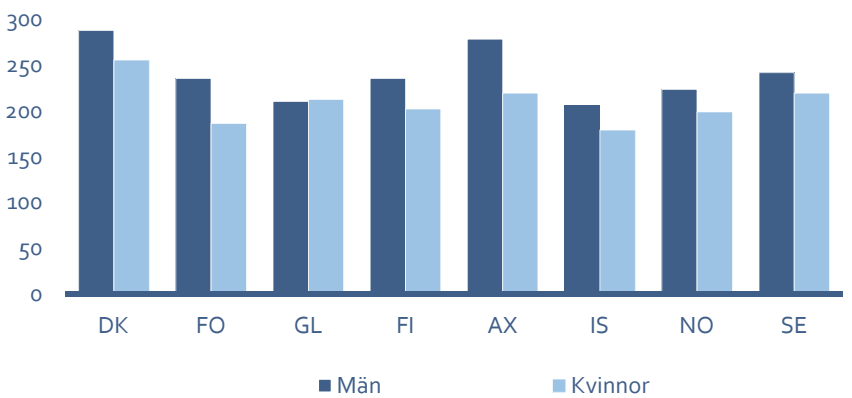

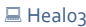


Summerade fruktsamhetstal 2016

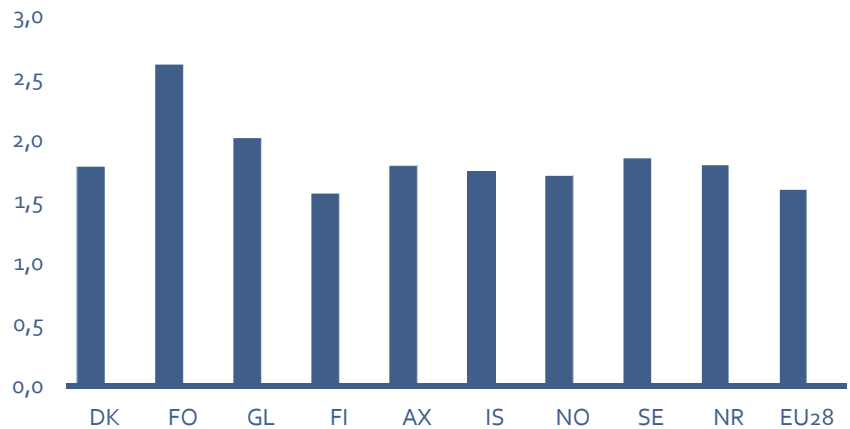

므 Chilo2. Grönland: 2015 års uppgifter.

Medellivslängd 2016

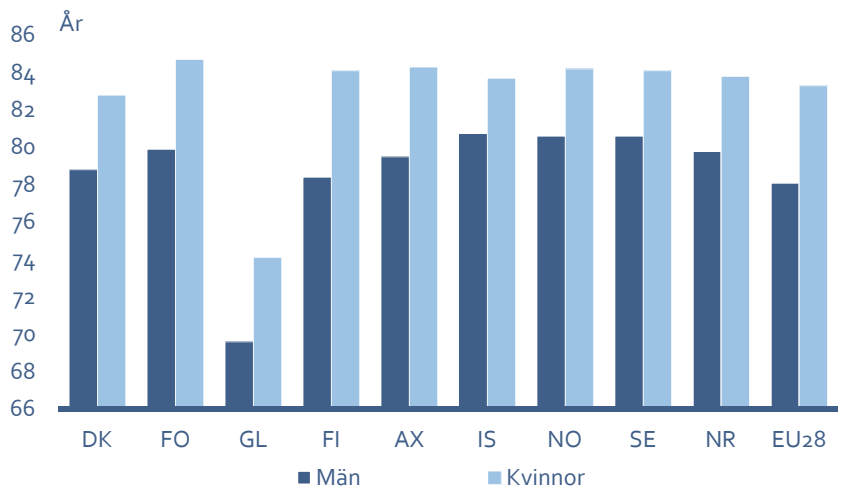

믄. Lifeo1. Grönland, Åland och EU28: 2015 års uppgifter. 
Asylansökningar i Norden 2016

Andel av ansökningarna

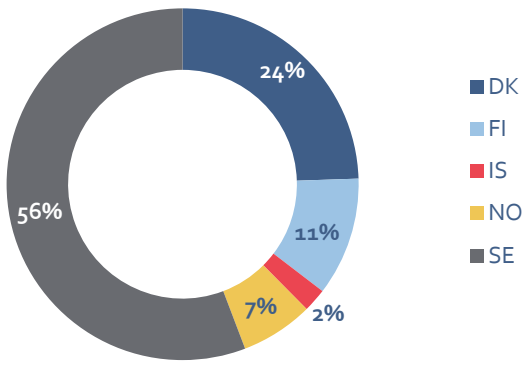

Migro4

Asylansökningar och beviljade asyl i Norden

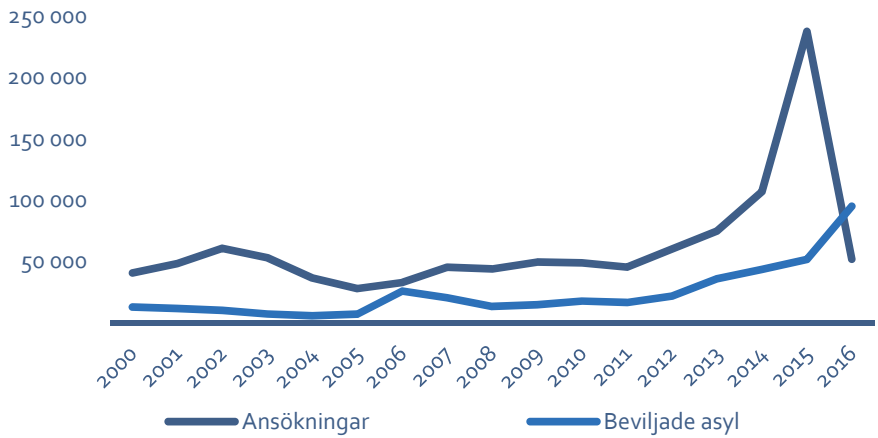

Migro4 


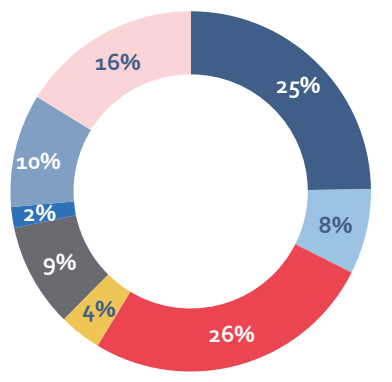

- Inom Norden

Polen och Baltikum

—Övriga EES

- Övriga Europa

Amerika

Afrika

Asien

Övriga

Migro2

Invandring till Norden 2016

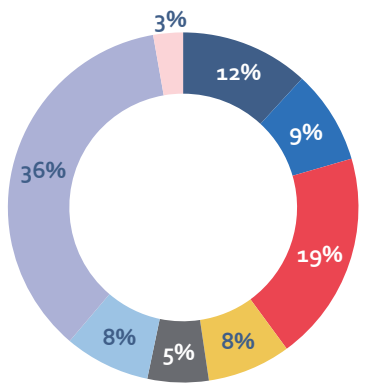

- Inom Norden

- Polen och Baltikum

- Övriga EES

- Övriga Europa

- Amerika

Afrika

Asien

¿̈vriga

昷 Migro1 


\section{Barn och unga}


Populäraste namnen bland nyfödda 2016

DANMARK

GRÖNLAND

FÄRÖARNA

FINLAND

ÅLAND

ISLAND (2015)

NORGE

SVERIGE

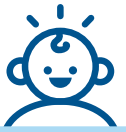

Sofia Nivi

Anna

Sofia

Alice

Emilia

Nora

Alice

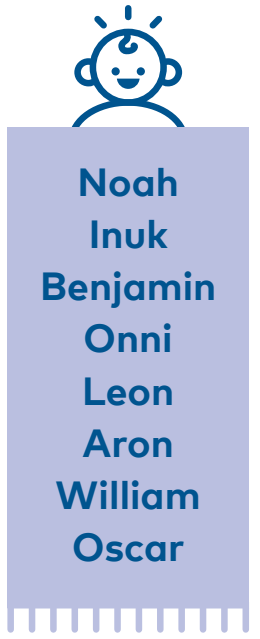




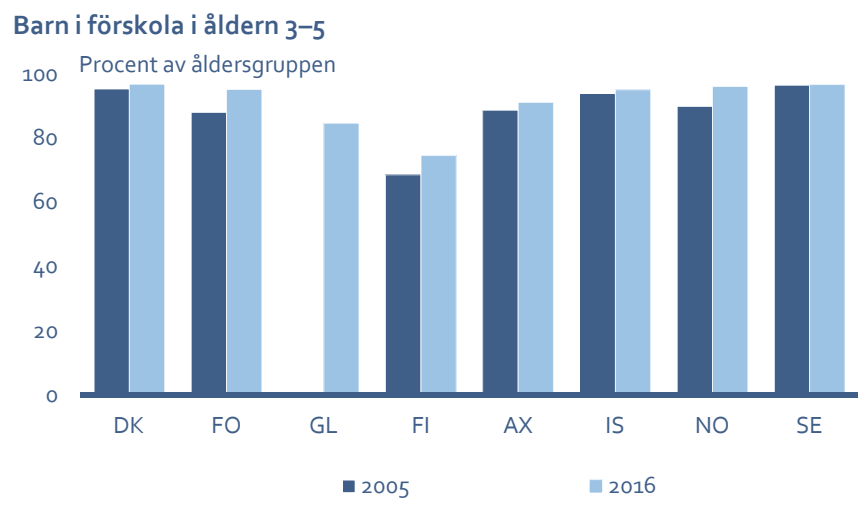

묘으. Chilo3. Danmark: 2014 års uppgifter. Finland och Island: 2015 års uppgifter.

Ökning av årlig ekvivalerad inkomst från 2005 till 2015

6o Procentuell ökning

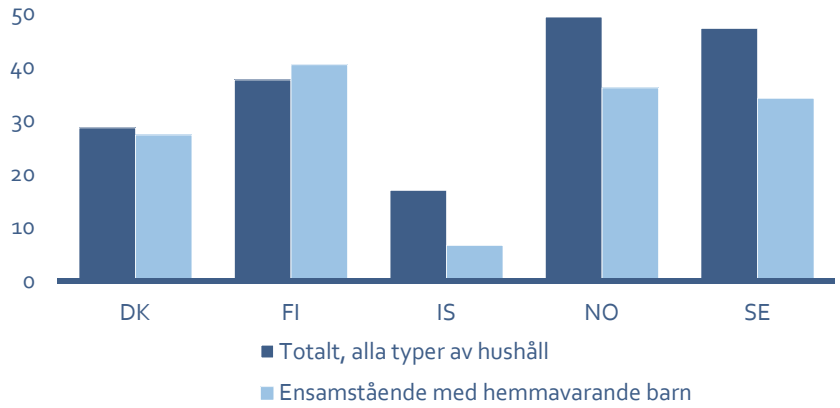

@ Incoo2 


\section{Elevers prestationer PISA 2015}

\begin{tabular}{|c|c|c|c|c|c|}
\hline \multicolumn{2}{|l|}{ Läsförståelse } & \multicolumn{2}{|c|}{ Kunskaper i matematik } & \multicolumn{2}{|c|}{ Kunskaper i naturvetenskap } \\
\hline Kanada & 527 & Japan & 532 & Japan & 538 \\
\hline Finland & 526 & Sydkorea & 524 & Estland & 534 \\
\hline Irland & 521 & Schweiz & 521 & Finland & 531 \\
\hline Estland & 519 & Estland & 520 & Kanada & 528 \\
\hline Sydkorea & 517 & Kanada & 516 & Sydkorea & 516 \\
\hline Japan & 516 & Nederländerna & 512 & Slovenien & 513 \\
\hline Norge & 513 & Finland & 511 & Nya Zeeland & 513 \\
\hline Tyskland & 509 & Danmark & 511 & Australien & 510 \\
\hline Nya Zeeland & 509 & Slovenien & 510 & Nederländerna & 509 \\
\hline Polen & 506 & Belgien & 507 & Tyskland & 509 \\
\hline Slovenien & 505 & Tyskland & 506 & Storbritannien & 509 \\
\hline Australien & 503 & Irland & 504 & Schweiz & 506 \\
\hline Nederländerna & 503 & Polen & 504 & Irland & 503 \\
\hline Danmark & 500 & Norge & 502 & Danmark & 502 \\
\hline Sverige & 500 & Österrike & 497 & Belgien & 502 \\
\hline Belgien & 499 & Nya Zeeland & 495 & Polen & 501 \\
\hline Frankrike & 499 & Australien & 494 & Portugal & 501 \\
\hline Portugal & 498 & Sverige & 494 & Norge & 498 \\
\hline Storbritannien & 498 & Frankrike & 493 & USA & 496 \\
\hline USA & 497 & Portugal & 492 & Österrike & 495 \\
\hline Spanien & 496 & Storbritannien & 492 & Frankrike & 495 \\
\hline OECD genomsnitt & 493 & Tjeckien & 492 & Sverige & 493 \\
\hline \multirow{5}{*}{$\begin{array}{l}\text { Schweiz } \\
\text { Lettland } \\
\text { Tjeckien } \\
\text { Österrike } \\
\text { Italien }\end{array}$} & 492 & OECD genomsnitt & 490 & Tjeckien & 493 \\
\hline & 488 & Italien & 490 & OECD genomsnitt & 493 \\
\hline & 487 & Island & 488 & Spanien & 493 \\
\hline & 485 & Spanien & 486 & Lettland & 490 \\
\hline & 485 & Luxemburg & 486 & Luxemburg & 483 \\
\hline Island & 482 & Lettland & 482 & Italien & 481 \\
\hline \multirow{2}{*}{$\begin{array}{l}\text { Luxemburg } \\
\text { Israel }\end{array}$} & 481 & Färöarna & 482 & Ungern & 477 \\
\hline & 479 & Ungern & 477 & Island & 473 \\
\hline Färöarna & 470 & Slovakien & 475 & Israel & 467 \\
\hline Ungern & 470 & USA & 470 & Slovakien & 461 \\
\hline Grekland & 467 & Israel & 470 & Grekland & 455 \\
\hline Chile & 459 & Grekland & 454 & Chile & 447 \\
\hline Slovakien & 453 & Chile & 423 & Färöarna & 446 \\
\hline Turkiet & 428 & Turkiet & 420 & Turkiet & 425 \\
\hline Mexiko & 423 & Mexiko & 408 & Mexiko & 416 \\
\hline
\end{tabular}

Pisao1 


\section{PISA 2015}

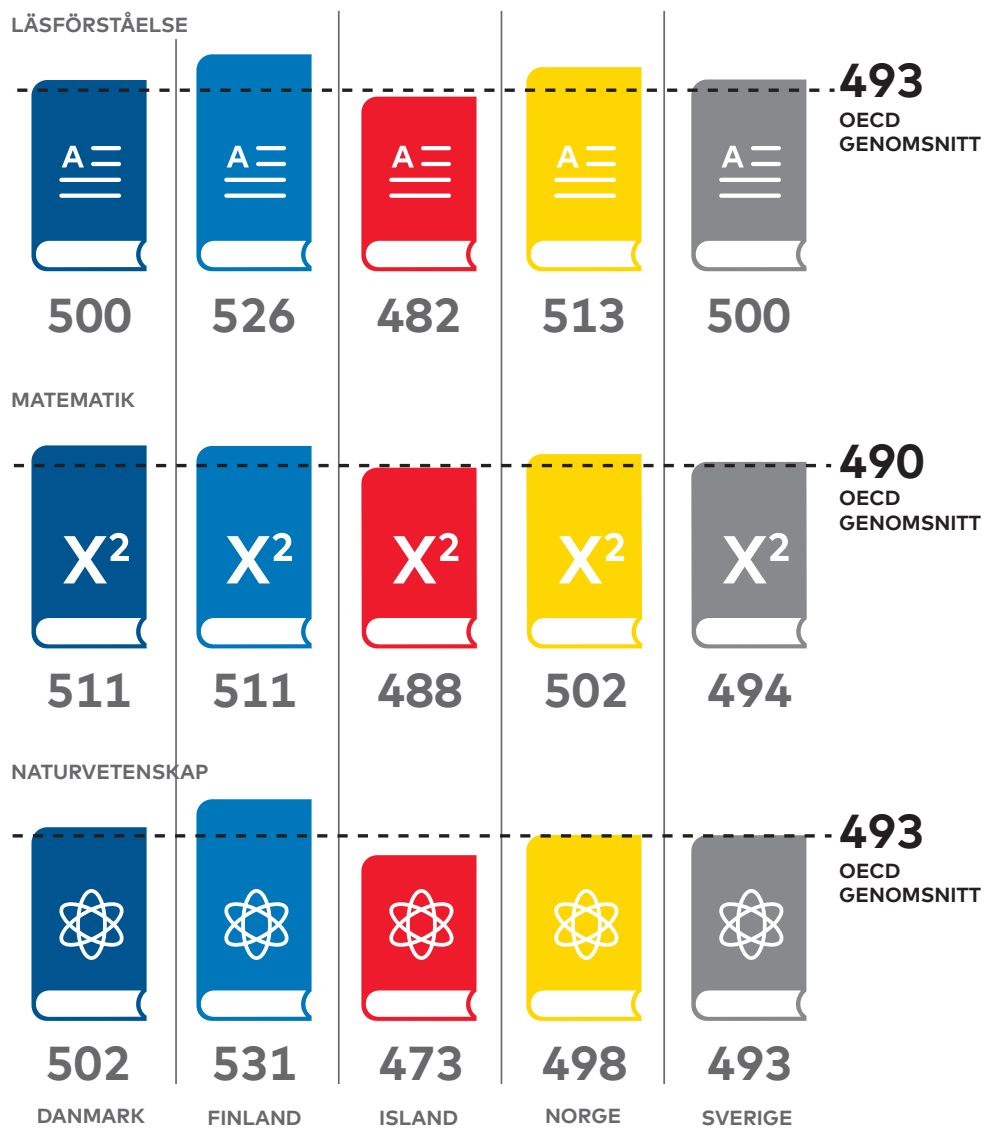


Inskrivna studenter på universitet och högskola 2015

Procent av åldersgruppen 20-39 år

20

18

16

14

12

10

8

6

4

2

0
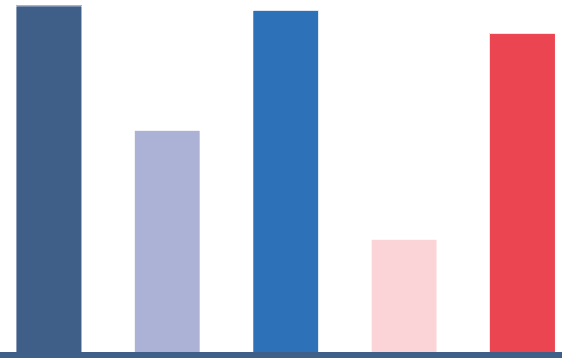

DK

GL

$\mathrm{FI}$

$\mathrm{AX}$

IS

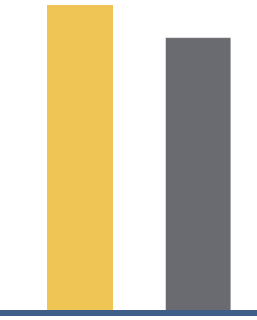

NO

SE

巨Educ02 och Popu02. Grönland: 2012 års uppgifter. Åland: Omfattar endast studenter vid Högskolan på Åland. Sverige: 2014 års uppgifter.

Inskrivna studenter på universitet och högskola

16 Procent av åldersgruppen 20-39 år, Norden totalt

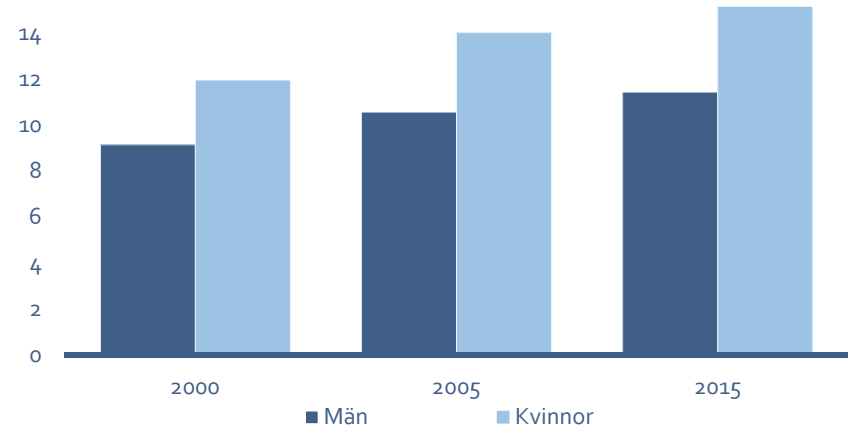

Educo2 och Popuo2 


\section{Studenter utomlands}

procent som studerar i ett annat nordiskt land

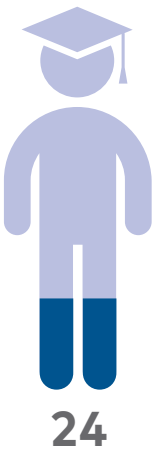

DANMARK

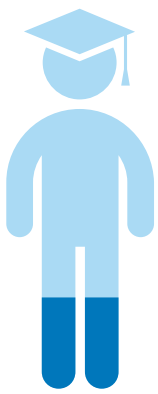

24

FINLAND

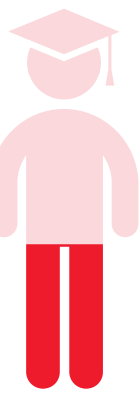

38

ISLAND
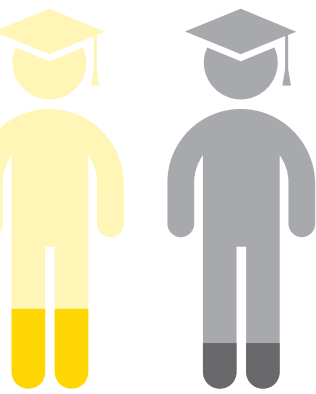

21

NORGE

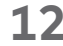

SVERIGE

Nordiska studerande i andra nordiska länder 2016

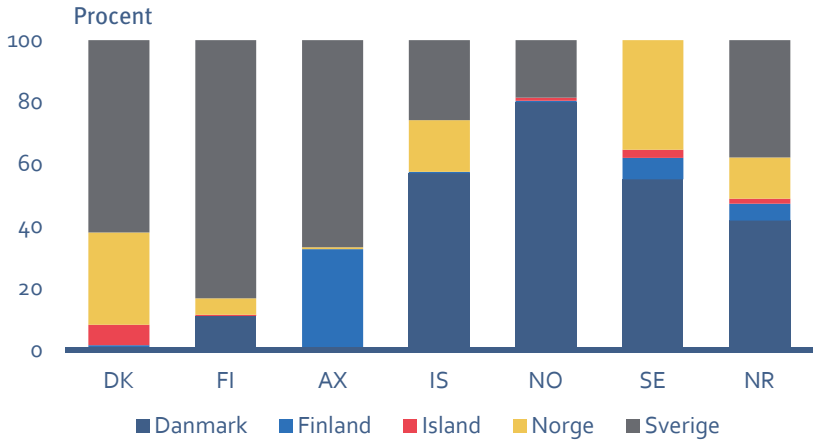


Ungdomsarbetslöshet

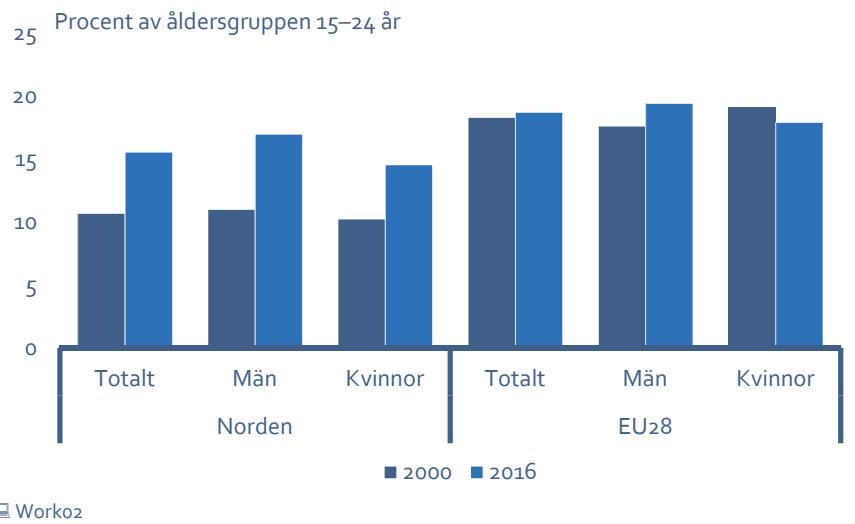





\section{Innovation och kreativitet}




\section{FoU-personal}

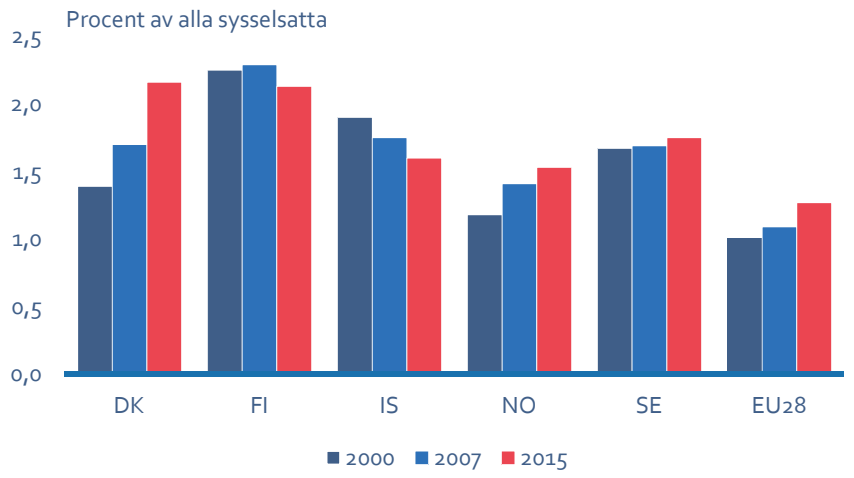

Rede04. Island: $2000=2003$ års uppgifter. Norge och Sverige: $2000=2001$ års uppgifter. EU28: $2000=2002$ års uppgifter.

\section{Totala statliga FoU-utgifter}

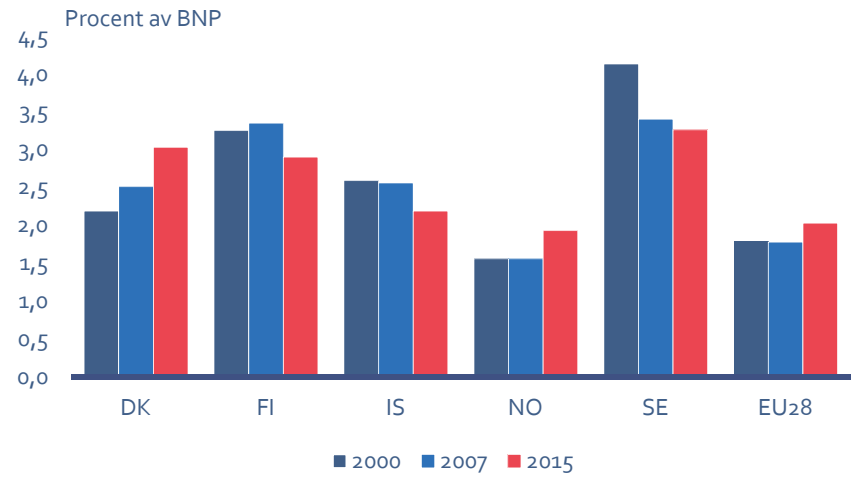

묘 Rede01. Norge och Sverige: $2000=2001$ års uppgifter. 


\section{Nybildade företag}

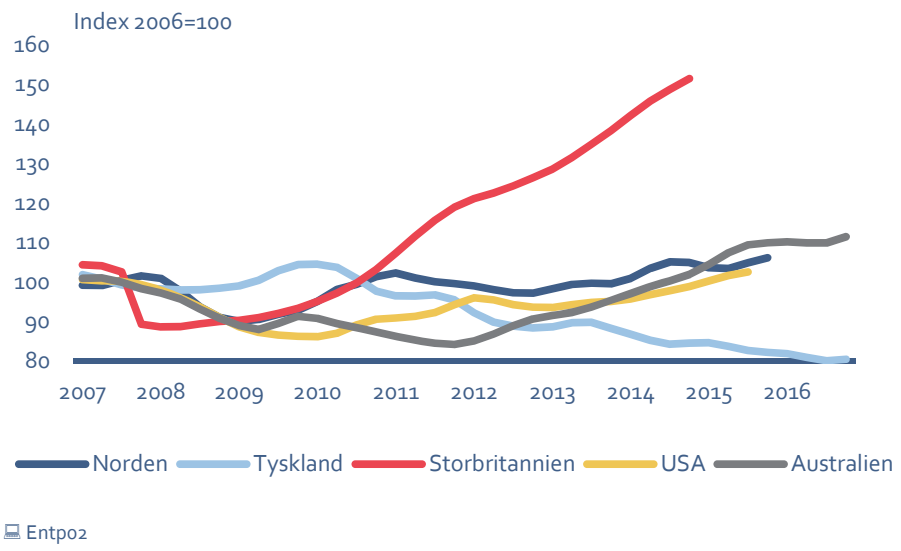

Patent 2016

600 Per miljon invånare

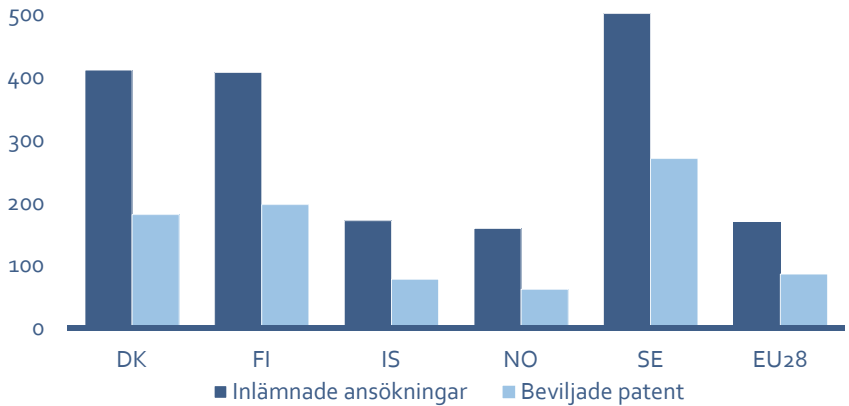

ㅁoteo1 


\section{Anställda inom kultursektorn}

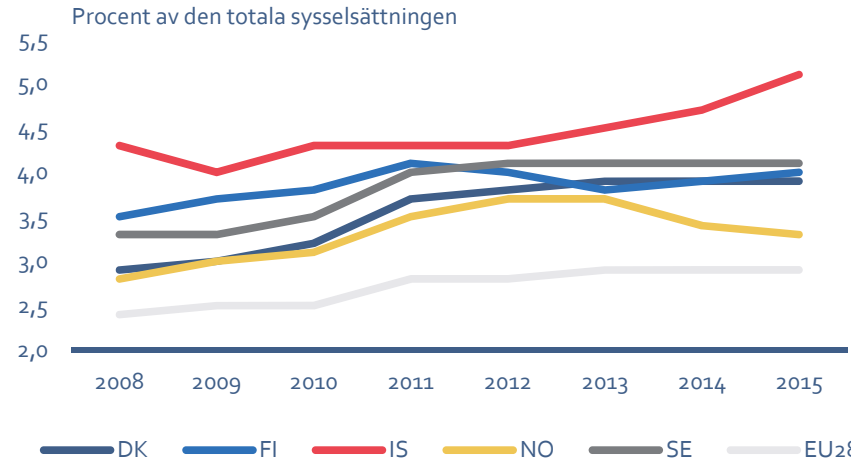

皿 Cult23

Offentliga utgifter till kultur och fritidsverksamhet 2015

Euro per invånare

1600

1400

1200

1000

800

600

400

200

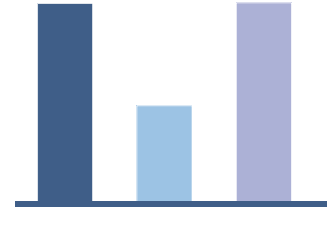

DK $\quad$ FO $\quad$ GL

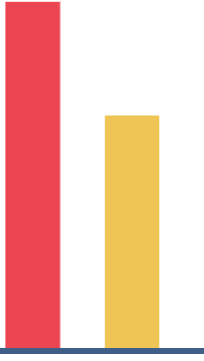

NO

SE

$\mathrm{EU}_{28}$

민 Cult20. Färöarna: 2013 års uppgifter. Grönland: 2012 års uppgifter. 
Offentliga utgifter till kultur och fritidsverksamhet

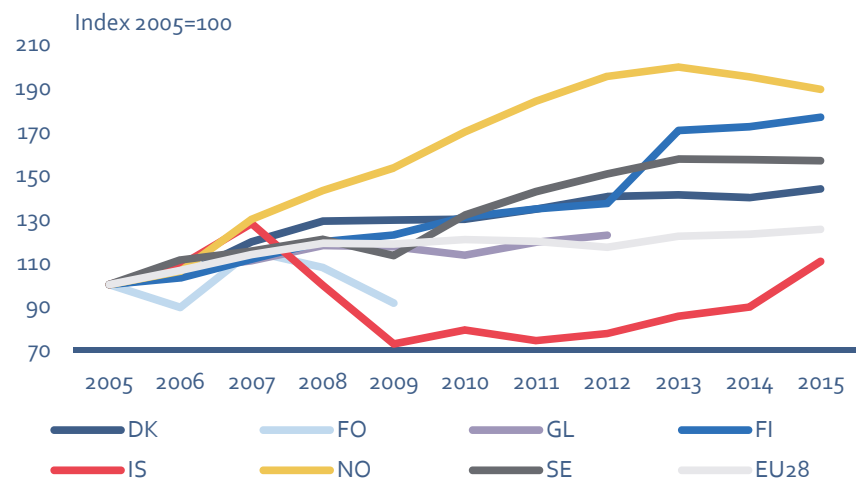

Cult2o

Filmpremiärer 2016

Andel av nordiska filmpremiärer

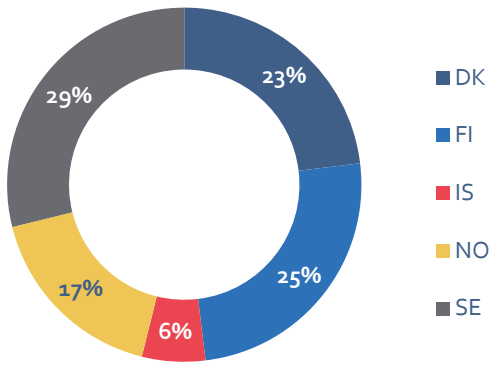

皿 Culto5 


\section{Filmpremiärer 2016}

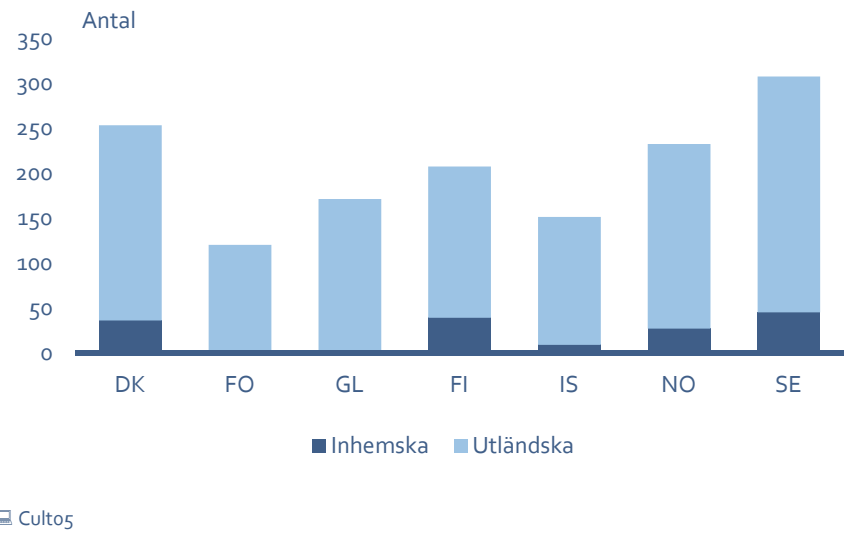

\section{Teaterbesök 2016}

Antal besök per 100 invånare

90

80

70

60

50

40

30

20

10

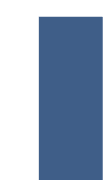

DK

FO

$\mathrm{GL}$

$\mathrm{FI}$
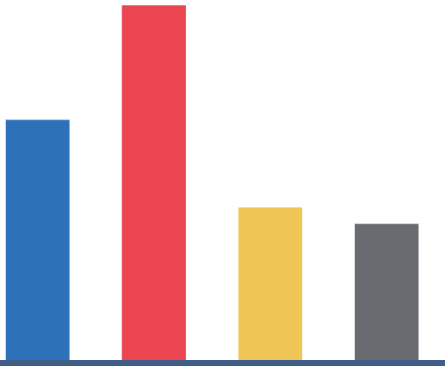

IS

NO

SE

묘 Cult15. Finland: 2015 års uppgifter. Island: 2014 års uppgifter. Sverige: 2010 års uppgifter. 
INNOVATION OCH KREATIVITET 55 
Ekonomi 
NYCKELTAL 2016

\section{Ekonomi}

Arbetslöshetstal

procent

DANMARK

6,3

FINLAND

9,0

ISLAND

3,1

NORGE

4,9

SVERIGE

8,4 


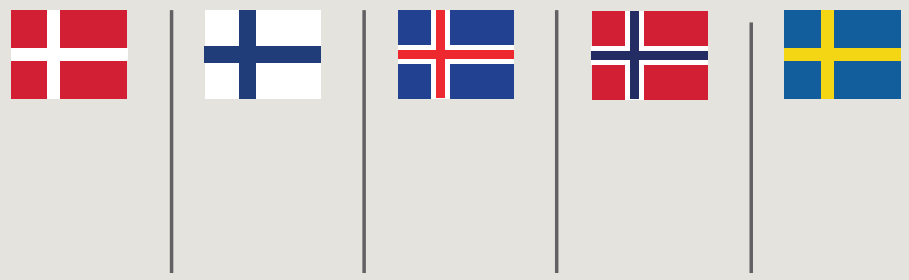

Ekonomisk tillväxt

procent

$$
\begin{array}{l|l|l|l|l}
1,3 & 1,4 & 7,2 & 1,0 & 3,3
\end{array}
$$

Bytesbalansöverskott

procent av BNP

Ränta

$$
\begin{array}{l|l|l|l|l}
8,2 & -1,1 & 7,9 & 4,9 & 4,7
\end{array}
$$

procent

$$
\begin{array}{l|l|l|l|l}
0,3 & 0,4 & 2,8 & 1,3 & 0,5
\end{array}
$$

Offentliga sektorns överskott procent av BNP

$$
\begin{array}{l|l|l|l|l}
-0,9 & -1,9 & 12,6 & 3,1 & 0,9
\end{array}
$$

Tillväxt i konsumentpriser 2015-2016, procent

$$
\begin{array}{l|l|l|l|l}
0,3 & 0,4 & 0,8 & 3,9 & 1,1
\end{array}
$$




\section{Bruttonationalprodukt, årlig realtillväxt}

Procent

\section{5}

10

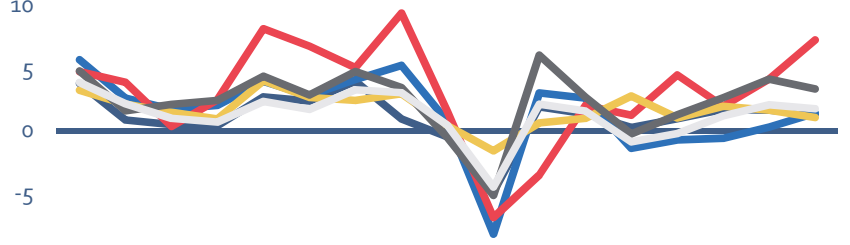

$-10$

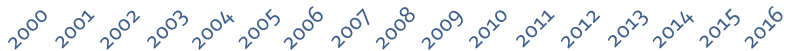

$$
\begin{aligned}
& \text { DK } \\
& \longrightarrow \mathrm{FI} \longrightarrow \\
& \longrightarrow \mathrm{NO} \longrightarrow \mathrm{SE}
\end{aligned}
$$

Nac02. EA19: De 19 europeiska länder som har infört euron som gemensam valuta per 1 januari 2015 .

\section{Bruttonationalprodukt per person}

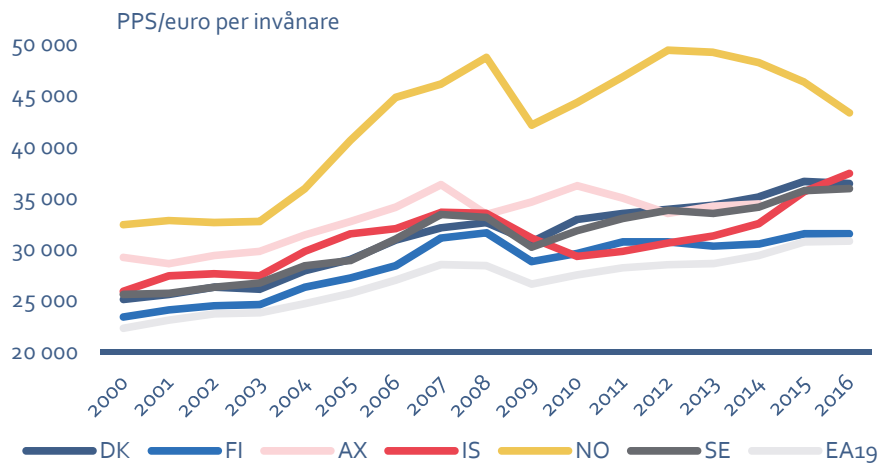

a. Nac04. PPS: Purchasing power standards - köpkraftspariteter som eliminerar skillnader i prisnivå mellan länderna. 


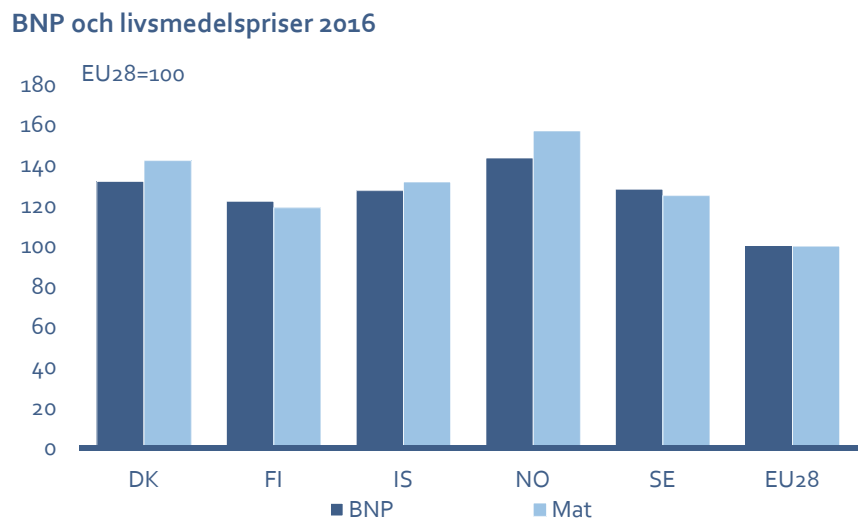

口 Prico3

Huspriser

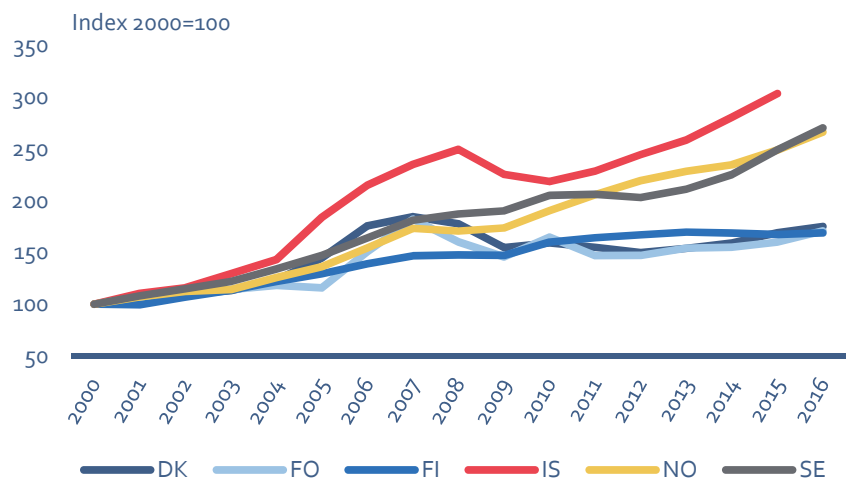

ㅁico5 
Handel med varor mellan de nordiska länderna

Procent av den totala exporten

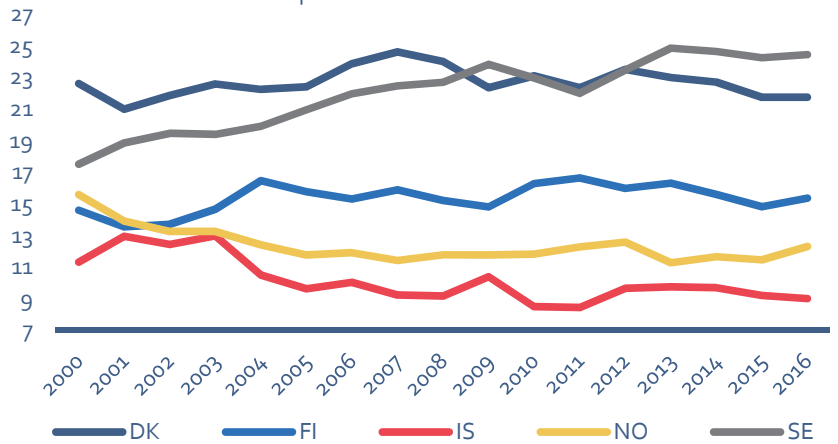

Eotr49

Handel med varor mellan de nordiska länderna

Procent av den totala importen

32

30

28

26

24

22

20

18

16

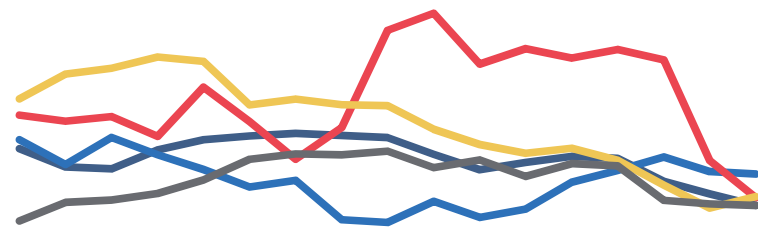

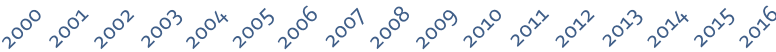

DK

$\longrightarrow \mathrm{FI}$

$\longrightarrow$ IS

NO

SE

旦otr49 
Handelsbalans för varor - export minus import

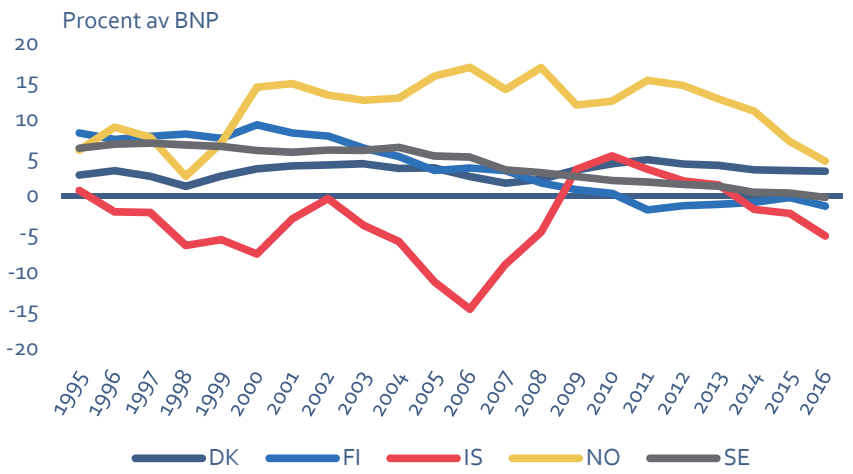

․ Fotr49 och Naaco1 
Nordiska ministerrådet

Nordens Hus

Ved Stranden 18

DK-1061 Köpenhamn K

www.norden.org

ANP 2017:747

ISBN 978-92-893-5097-6 (PRINT)

ISBN 978-92-893-5098-3 (PDF)

ISBN 978-92-893-5099-0 (EPUB)

ISSN 2414-6560 (ONLINE)

ISSN 2414-6552 (PRINT) 